\title{
STRATEGI TRANSPORTASI BATUBARA - MEMBANDINGKAN OVERLAND CONVEYING DENGAN TRUK PENGANGKUT BATUBARA
}

\author{
Supris Rudianto $^{1)}$ dan Tikto Hartanto ${ }^{1)}$ \\ ${ }^{1)}$ Coal Preparation Plant Operation Department, PT. Kaltim Prima Coal
}

\begin{abstract}
ABSTRAK
Pada tahun 2005 PT Kaltim Prima Coal (KPC) melakukan kajian proyek peningkatan bisnis untuk mengembangkan operasi tambang Sangatta. Kajian difokuskan pada peningkatan kapasitas produksi 34-35 Metrik Ton per Tahun (JTPT) saat itu, menjadi 44 JTPT dan sampai dengan 70 JTPT. Inisiatif pengurangan biaya produksi karena meningkatnya jarak tempuh, kenaikan harga bahan bakar dan kelangkaan ban pada tahun 2005 dimasukan sebagai fariabel eksogen penting dalam kajian ini. Kajian yang dilakukan meliputi strategi pemilihan transportasi batubara dengan cara membandingkan moda transportasi batubara mengunakan conveyor system terhadap mode pengangkutan menggunakan truk. Hasilnya mode transportasi conveyor system lebih unggul dari sisi produktifitas, kontinuitas produksi, umur layanan operasi yang lebih lama, biaya operasi \& maintenance yang lebih rendah dan lebih handal untuk lokasi tambang yang terbatas dengan kecuraman medan sampai pada tingkat $30^{\circ}-35^{\circ}$. Dengan dasar pertimbangan teknis dan ekonomis, proyek peningkatan bisnis ini ditindak lanjuti dengan melakukan tujuh proses kajian secara internal. Tahapan berikutnya adalah analisa keekonomian dengan memasukan lima belas variabel untuk menentukan satu dari 3 alternatif pembiayaan yang tersedia. Hasil analisa dari 3 alternatif tersebut akan diambil keputusan dengan membandingkan dua parameter utama yakni Net Present Value dan Internal Rate Return. Analisa ekonomi dipertajam dengan uji sensitifitas untuk melihat respond NPV terhadap pengaruh variabel produksi, pasokan pembangkit listrik, biaya modal, dan biaya truk pengangkut. Rangkaian kajian dan evaluasi tersebut menghasilkan keputusan pembangunan Melawan Crushing Station \& Western Overland (OLC) yang berlokasi ditengah lokasi tambang Melawan area dengan disain dasar berkapasitas rata-rata 4.000 ton per jam.
\end{abstract}

Kata Kunci: Strategi transportasi batubara, Melawan Crushing Station \& Western OLC, pertimbangan aspek teknis dan analisis ekonomis

\begin{abstract}
KPC conducted a business improvement project study to develop Sangatta mining operations in 2005. The study focused on increasing production capacity from 34 to 35 Metric Tons per Year (MTPY) to 44 MTPY and up to 70 MTPY. Initiatives to reduce production costs due to increased mileage, rising fuel prices and tire scarcity in 2005 were included as exogenous variables in this study.The study focused on strategy for selecting coal transportation modes by comparing conveyor transporting system to trucking mode. The study resulted that the conveyor system transportation mode was superior in terms of productivity, production continuity, longer service life cycle, lower operating \& maintenance costs and more reliable for finite mine sites with steepness of terrain up to the level of $30^{\circ}-35^{\circ}$. Based on technical and economic considerations, this business improvement project was followed up by conducting seven steps internal process study. The following stage was an economic analysis by entering fifteen variables to determine the best one from the 3 available financing alternatives. The results of the analysis of the 3 alternatives will be decided by comparing the two main parameters namely Net Present Value and Internal Rate Return. Economic analysis is sharpened with sensitivity testing to see NPV respond against the influence of production variables, power generation supplies, capital costs, and cost of transporter trucks. The course of studies and evaluations concluded to construct of Melawan Crushing Station
\end{abstract}


\& Western Overland. It would be placed at center of the Melawan mine site, with a basic design average capacity was 4,000 tons per hour.

Keyword: coal transportation strategy, Melawan Crushing Station \& Western Overland Conveyor, technical aspect consideration and economical analysis

\section{A. PENDAHULUAN}

PT. Kaltim Prima Coal (KPC) secara tradisional mengangkut batubara dari tambang ke stasiun peremukan batubara atau crushing plant menggunakan truk type 80T sampai dengan $125 \mathrm{~T}$. Beberapa tahun terakhir ini proporsi produksi batubara KPC mengalami peningkatan yang cukup siknifikan. Demikian pula dengan lokasi tambang KPC sudah sangat jauh dari lokasi peremukan batubara. Tambang KPC Sangatta secara progresif berkembang ke arah Barat yakni Melawan area dan ke arah Utara yakni Pit AB Area. Sehingga waktu pengangkutan batubara dari lokasi tambang terjauh menuju stasiun peremukan bisa memakan waktu lebih dari satu jam untuk setiap pengangkutan.

Pada saat yang sama pada tahun 2005, subsidi biaya bahan bakar secara progresif ditarik oleh pemerintah Republik Indonesia (RI). Tepat pada 1 July 2005, pemerintah RI menarik secara penuh subsidi bahan bakar ini. Penarikan subsidi ini bertepatan dengan periode harga minyak dunia yang tinggi dibandingkan dengan harga sepuluh tahun terakhir.

Pararel dengan kenaikan harga bahan bakar, pasar dunia untuk ban alat berat (heavy earth moving tyre) mengalami kekurangan pasokan. Hal ini mempengaruhi ketersediaan ban radial untuk truk pengangkut batubara, sehingga KPC terpaksa menggunakan ban dengan bias ply. Ban dengan bias ply mempunyai keterbatasan pada kecepatan dan jarak tempuhnya. Bagi KPC, kelangkaan pasokan ban meningkatkan resiko ketidak tersediaan ban yang dibutuhkan guna mencapai target produksi KPC.

Kenaikan harga bahan bakar dan kelangkaan ban alat berat mengakibatkan biaya rata-rata pangangkutan batubara sangat tinggi. Bagi KPC, situasi ini memberikan dampak kenaikan biaya operasi secara substansial sampai dengan USD175 Milions (M) dibandingkan dengan biaya operasi pada tahun 2003 dengan tingkat produksi yang sama (KPC, 2006). Kenaikan dramatis dalam harga bahan bakar dan ban serta dikombinasikan dengan resiko kurangannya pasokan ban dan jarak tambang yang semakin jauh serta terbukanya peluang untuk meningkatkan kapasitas produksi telah mendorong untuk menempatkan prioritas inisiatif penggurang biaya dari operasi transportasi batubara sebagai prioritas terdepan. Akan tetapi dengan inisiasi penggurangan biaya operasi pada kapasitas produksi yang sama pada saat itu tentu saja tidak cukup dalam mempertahankan dan meningkatkan pendapatan dan laba KPC. Sehingga selama tahun 2005 sampai dengan 2006, KPC melakukan kajian proyek peningkatan bisnis untuk mengembangkan operasi tambang Sangatta. Kajian ini difokuskan pada peningkatan kapasitas produksi dari 34-35 Metrik Ton per Tahun (JTPT) menjadi 44 JTPT dan sampai dengan 60 JTPT. Hasil kajian atas proyek peningkatan bisnis ini memberikan rekomendasi kelayakan peningkatan kapasitas produksi terintegrasi dengan pembangunan proyek ekspansi Melawan Crushing Station dan Western OLC.

Sebagai bentuk kepatuhan KPC pada peraturan pemerintah Republik Indonesia, keputusan untuk pengembangan kapasitas produksi tambang KPC tersebut masuk dalam studi AMDAL KPC. Dalam studi AMDAL KPC 2010 tersebut dilaporkan bahwa cadangan batubara terbukti KPC hampir $43 \%$ dari tambang Melawan Area dan dimana produksi KPC kedepan hampir 50\% akan berasal dari lokasi ini (2010, p.II-29). Sehingga rekomendasi kelayakan peningkatan kapasitas produksi sudah sesuai dengan rencana jangka panjang produksi KPC seperti yang digambarkan 
dalam peta rencana kemajuan Tambang Sangatta seperti gambar 2 dan rencana kapasitas produksi dalam tabel 1.

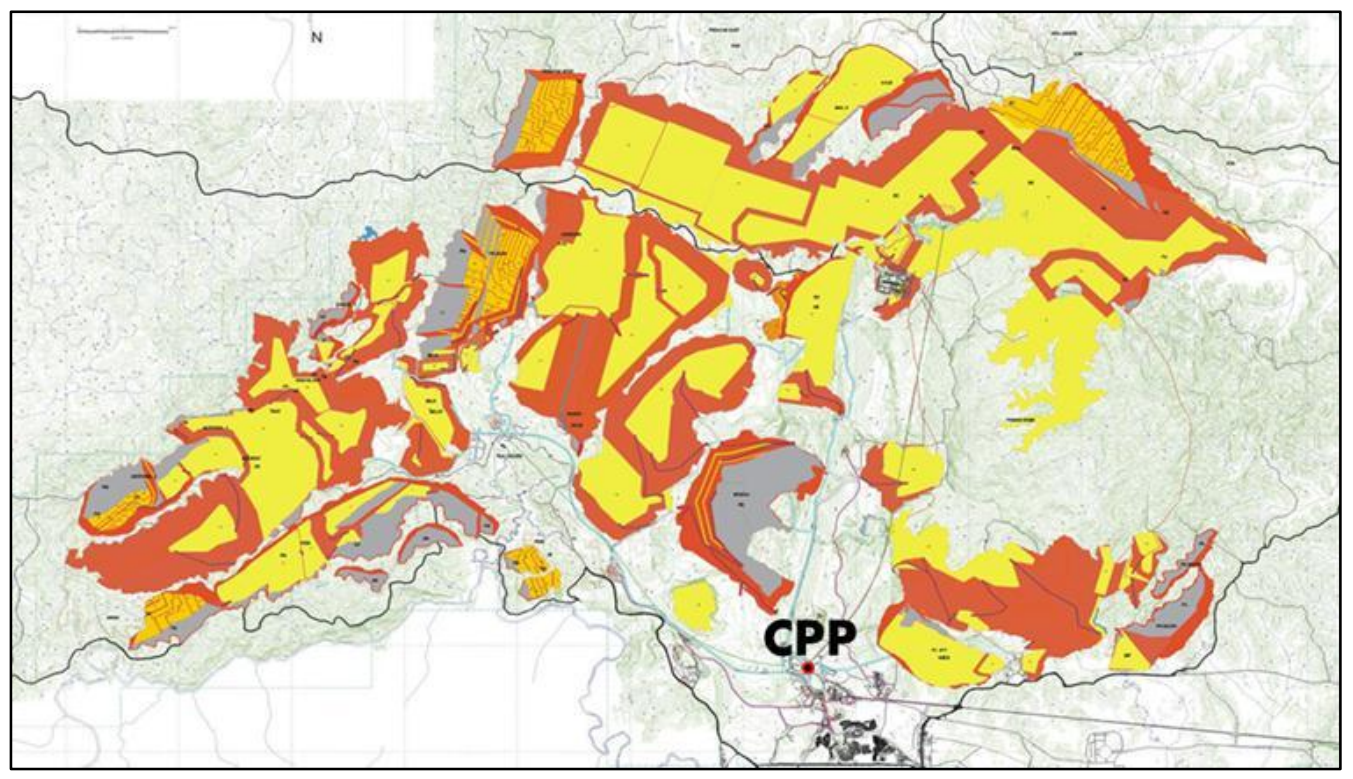

Gambar 1. Peta Rencana Kemajuan Tambang Sangatta Akhir Tahun 2020

Tabel 1. Rencana Produksi Tambang Melawan Area LOM Versi 3-2007

\begin{tabular}{cc}
\hline Tahun & Rencana Produksi \\
\hline 2009 & 18,477 \\
2010 & 18,813 \\
2011 & 17,986 \\
2012 & 17,178 \\
2013 & 17,793 \\
2014 & 17,456 \\
2015 & 15,780 \\
2016 & 13,702 \\
2017 & 20,630 \\
2018 & 20,144 \\
2019 & 15,625 \\
2020 & 8,455 \\
2021 & 7,610 \\
\hline
\end{tabular}

Dalam menghadapi permasalahan biaya operasi sekaligus menyambut tantangan peningkatan produksi, selanjutnya KPC mendorong terealisasinya proyek peningkatan bisnis dengan melakukan kajian lebih lanjut. Kajian ini mencakup studi literatur dan penelitian aplikasi $O L C$ seluruh dunia terutama pada $O L C$ kurva horisontal (horizontal curved) serta analisa ekonomi sebagai metodologi utama yang dijadikan acuan untuk memastikan tujuan proyek peningkatan bisnis tercapai. Analisa ekonomi pada operasi transportasi batubara akan membandingkan biaya operasi truk pengangkut batubara dengan biaya kapital dan operasi dari realisasi proyek Melawan Crushing Station dan Western $O L C$ berdasar kepada rencana produksi tahunan dari tambang Melawan Area. Parameter analisa ekonomi yang akan dihitung dan dijadikan acuan keputusan adalah Net Present Value (NPV) dan Internal Rate of Return (IRR) serta Payback Period atau jangka waktu pengembalian investasi. 


\section{B. PEMBAHASAN}

KPC sendiri sejak tahun 1992 telah mengoperasikan OLC kurva vertical (vertical curved) dengan panjang tiga belas kilometer dan terbukti beroperasi dengan baik. Sementara itu dalam industri tambang, aplikasi $O L C$ kurva horizontal dengan satu aliran sudah terpasang dan beroperasi sejak tahun 1998. Conveyor Dynamics, Inc. (CDI) yang telah mengerjakan desain OLC kurva horizontal dengan panjang 15.6 kilometer dalam satu aliran dengan menggunakan teknologi tahanan putaran rendah (rolling resistance) sehingga memberikan konsumsi daya listrik rendah (CDI, 1998). Disamping itu conveyor system dapat memberikan kelebihan pengangkutan material dibanding dengan mode trucking. Conveyor system mampu mengatasi kondisi keterbatasan lokasi tambang, jarak, dan kecuraman medan sampai pada tingkat $30^{\circ}-35^{\circ}$. Sementara truk pengangkut batubara hanya mampu beroperasi pada jalan dengan tingkat kecuraman $6^{0}-8^{0}$. Dasi sisi kontinuitas produktifitas, conveyor system lebih ungul dengan dapat beroperasi secara kontinu 24 jam per hari 7 hari dalam sepekan tanpa harus berhenti. Truk pengangkut batubara tidak bisa beroperasi secara kontinu karena keterbatasan unitnya sendiri dan operatornya.

Dari data operasi KPC telah membuktikan operasi $O L C$ dapat mencapai dan memberikan ketersediaan fisik (physical availability) 95\% dibandingkan dengan trucking system hanya dapat mencapai $66 \%$. Ketika rencana umur tambang yang cukup panjang, OLC mampu memberikan pelayanan operasi sampai dengan tiga puluh tahun. Dalam operasi $O L C$ tersebut, sabuk konveyor (conveyor belt) merupakan komponen utama yang membutuhkan penggantian sekali dalam lima belas tahun. Dibandingkan dengan operasi truk pengangkut batubara dengan sistem pemeliharaan yang sangat baik hanya mampu memberikan pelayanan operasi sampai dengan duapuluh tahun dengan 6 kali major overhaul yang biayanya bisa lebih dari hampir 4 kali pembelian truk baru. Dari beberapa faktor ini jelas menunjukkan Overland Conveyor lebih unggul dari mode transportasi dengan truk pengangkut.

Mengacu kepada Conveyor Equipment Manufacturers Association (CEMA), secara ekonomis ada beberapa aturan praktis (rules of thumb) yang memberikan indikasi biaya instalasi OLC lebih rendah dibandingkan dengan truk pengangkut. Akan tetapi biaya ini harus dievaluasi secara individual untuk setiap instalasi $O L C$. Beberapa aturan praktis yang dipergunakan secara luas dan tidak terbatas kepada parameter sebagai berikut (2007, p. 13):

1. Operasi $O L C$ lebih ekonomis dibandingkan dengan truk pengangkut ketika jarak angkut lebih dari satu kilometer.

2. Jarak diatas satu kilometer, biaya transportasi ton-kilometer dengan konveyor lebih rendah sepersepuluh dari biaya menggunakan truk pengangkut.

Dengan dasar pertimbangan teknis dan ekonomis yang cukup kuat, keputusan strategis untuk proyek peningkatan bisnis ini ditindak lanjuti dengan dilakukannya beberapa kajian secara internal KPC yang antara lain: penilaian resiko bisnis tingkat tingkat tinggi; finalisasi survei pendahuluan dan kajian geoteknik; optimisasi lokasi stasiun peremukan, rute konveyor darat dan stasiun transfer ke stasiun yang ada; kajian rekayasa pendahuluan untuk transmisi dan distribusi sumber listrik; pengembangan pernyataan definisi proyek, ruang lingkup dan spesifikasinya, gambar rekayasa pendahuluan dan jadwal proyek mengacu kepada kontek produksi KPC; dan serta secara paralel melakukan kajian kapital dan analisa ekonomis guna mengajukan permintaan pembiayaan kapital. Maka proyek pembangunan Melawan Crushing Station dan Western OLC ditentukan pada posisi tengah dari lokasi tambang Melawan Area seperti pada gambar 2 dibawah ini (KPC, 2010). 


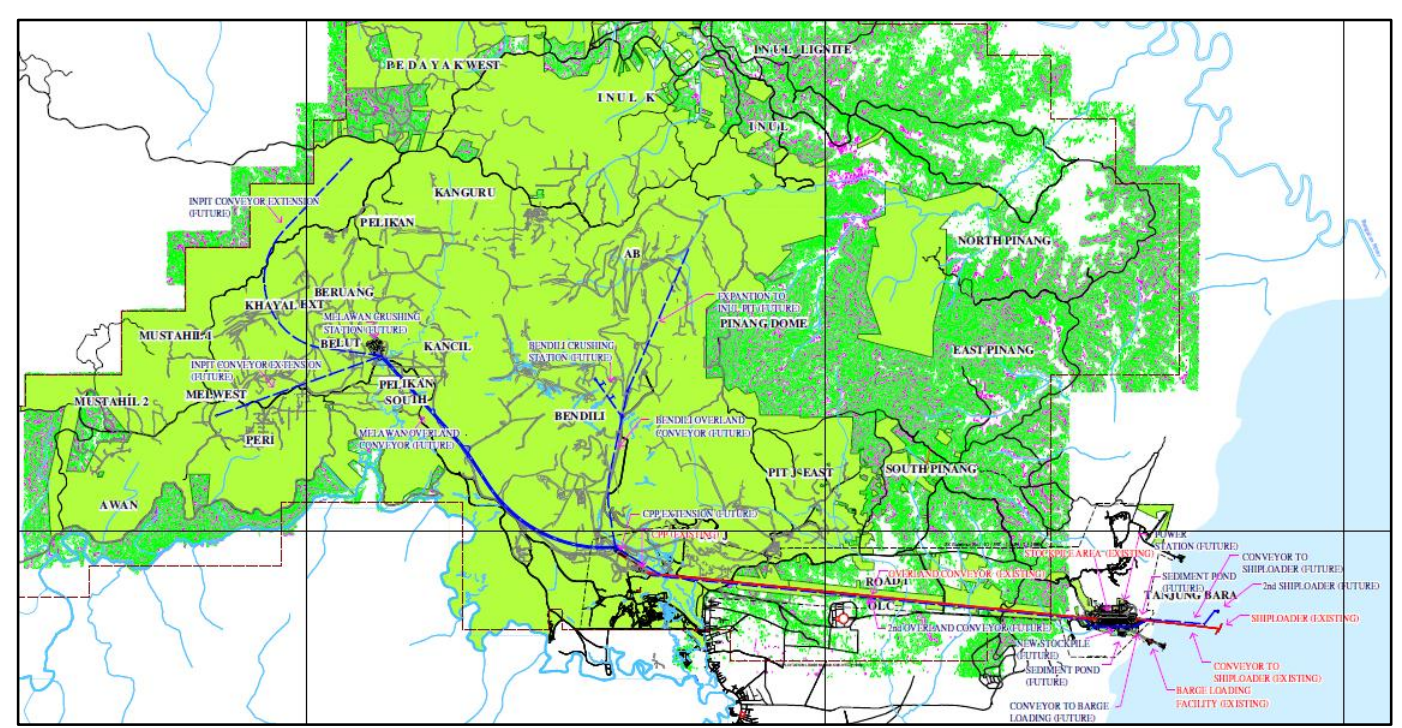

Gambar 2. Letak Proyek Crushing Station dan Western OLC terhadap tambang Melawan Area

Selanjutnya proyek pembangunan Melawan Crushing Station dan Western Overland Conveyor ini mengacu kepada Project Definition Statement (2010) mencakup desain dasar dan lingkup proyek yang terdiri dari sebagai berikut:

1. Crushing system dan Overland Conveyor dengan kapasitas rata-rata 4.000 ton per jam dan kapasitas puncak 4.500TPJ. Desain ini disesuaikan dengan kapasitas conveyor stream batubara yang sudah ada yang terhubung secara kontinu dari tambang sampai pelabuhan, dan mempunyai kesamaan komponen dan suku cadang guna menekan biaya operasi dan pemeliharaan

2. Desain Crushing system dan Overland Conveyor dilengkapi variable frekwensi yang fleksible, sehingga mampu beroperasi pada beberapa variasi kecepatan. Desain ini memungkinkan sistem bekerja pada kapasitas tertentu sesuai kebutuhan produksi dan pencampuran batubara.

3. Run of Mine (ROM) area yang dilengkapi dengan 2 fasilitas penumpukan atau Stockpile dan Kabin Operator ROM Base

4. 2 fasilitas penerima Dump Hopper yang mampu menerima truk pengangkut batubara dengan sistem rear dump pada dua sisi stasiun penerimaan. Desain ini dilengkapi dengan Chain Feeder, Primary Feeder Breaker, Transfer Conveyor, Belt Weigher, Magnetic Separators, Metal Detectors, dan Secondary Sizer Breaker.

5. Surge Bin 400T dilengkapi dengan Belt Feeder, Overland Conveyor sepanjang 9.2 Kilometer, Transfer Tower 150T, Coal Sampling Station dan Transfer Conveyor. Sistem baru ini dihubungkan dengan fasilitas pengelolaan batu batubara yang ada di Conveyor $\mathrm{CV}-02$

Berdasar diagram alir proses produksi batubara, lingkup proyek Melawan Crushing Station dan Western Overland Conveyor dapat dilihat pada gambar3, sementara itu hubungan dengan fasilitas pengelolaan batu batubara yang sudah ada bisa dilihat pada gambar 4 dibawah.

Hasil kajian yang sudah dilakukan secara internal terutama yang menyangkut lokasi, rute, definisi, desain dasar, ruang lingkup dari proyek maka dapat ditentukan estimasi biaya dari proyek. Selanjutnya analisa keekonomian dari proyek bisa dilakukan guna menentukan kelayakan proyek untuk bisa segera ditindak lanjuti untuk direalisasikan. Dalam Justification of Western OLC (KPC, 2007) analisa ekonomi menggunakan dasar pengurangan biaya pengangkutan batubara dan pemeliharaan jalan angkut dengan investasi modal pada proyek ini. Komponen konsumsi bahan bakar dan ban menjadi porsi terbesar pada pengurangan biaya pengangkutan batubara. Hasil evaluasi ini juga memberikan hasil positif berkenaan pengurangan risiko gangguan produksi yang mungkin terjadi karena kelangkaan ban truk pengangkut batubara. 


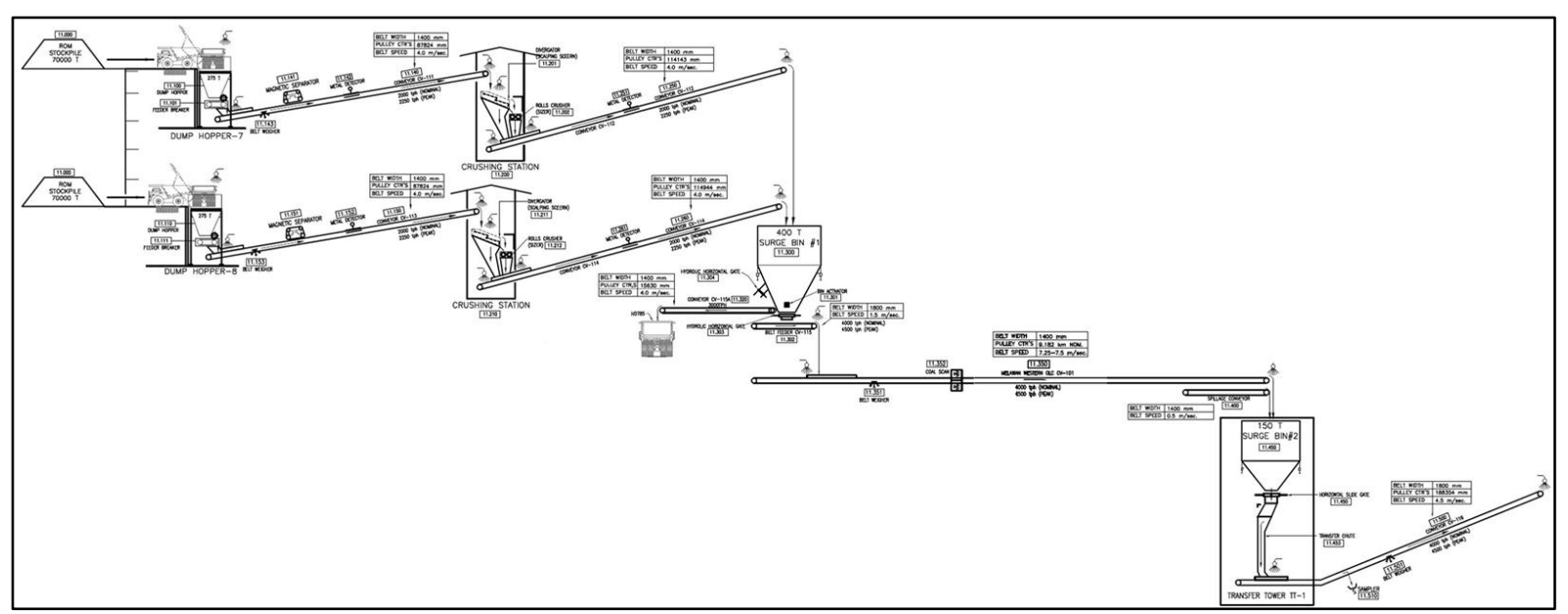

Gambar 3. Diagram Alir Lingkup Proyek Melawan Crushing Station \& Western Overland Conveyor

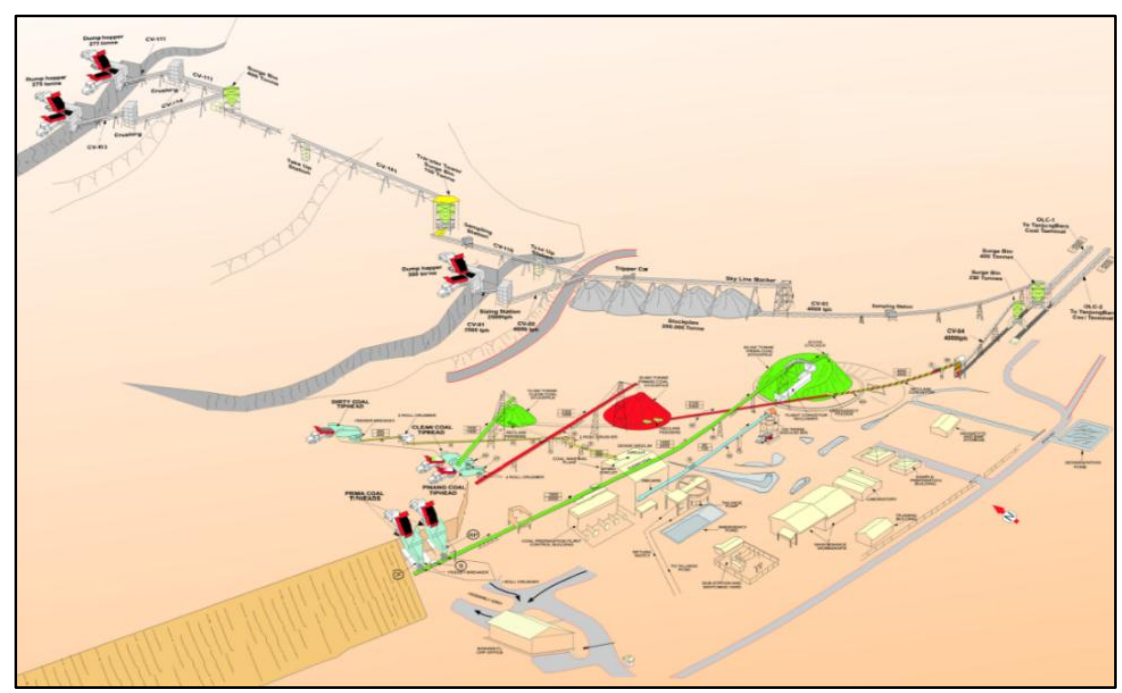

Gambar 4. Proyek Melawan Crushing Station \& Western OLC terhadap Fasilitas yang ada

Adapun parameter analisa yang digunakan antara lain adalah jangka waktu manfaat proyek 12 tahun sejak tahun 2009 atau sampai tahun 2021 dimana masa berakhirnya Pemegang Karya Pengusahaan Pertambangan Batubara (PKP2B) KPC, harga bahan bakar solar \$0.6/1 (jangka panjang), estimasi kapital +/- 20\% dengan kontingensi 15\%, suku bunga utang $12 \%$ per tahun dengan jangka utang 5 tahun termasuk 2 tahun masa konstruksi hanya bunga saja, nilai diskon nyata $15 \%$ per tahun setelah pajak, $45 \%$ pajak KPC dan 30\% tarif pajak sewa selama periode sewa 10 tahun, mengacu kepada rencana produksi jangka panjang dan biaya pengangkutan dari KPC Mine Plan, estimasi biaya listrik per kWh dari dari proyek KPC Power Expansion dengan eskalasi bahan bakar batubara/solar, operasi dan pemeliharaan 2,5\% per tahun, 3\% bea masuk nominal barang impor masterlisting, asuransi konstruksi $2 \%$ dan operasi 1\%, penyusutan PKP2B dan sewa garis lurus untuk 10 tahun lebih, dan terakhir masa konstruksi selama 2. Adapun pilihan untuk evaluasi pelaksanaan proyek ini menyangkut modal atau hutang KPC atau special purpose vehicle (SPV), proyek dilaksanakan dengan skema Engineering, Procurement, and Construction (EPC) dan pengoperasian dan pemeliharaan kedepannya akan dilakukan sendiri oleh KPC dengan pilihan yang tersedia adalah sebagai berikut:

1. KPC $100 \%$ penyertaan modal sendiri kontrak EPC/pembayaran progress

2. KPC 100\% sepenuhnya dibiayai hutang kontrak EPC /jadwal pelunasanhutang

3. KPC SPV $100 \%$ sepenuhnya dibiayai hutang kontrak EPC /jadwal pembayaran sewa 
Maka dari Justification of Western OLC (KPC, 2007) diperoleh hasil evaluasi dari analisa ekonomi ini memberikan rekomendasi untuk pelaksanaan proyek dengan pilihan kedua seperti pada tabel dibawah ini:

Tabel 2. Hasil Analisa Ekonomi

\begin{tabular}{cccc}
\hline & KPC 100\% & KPC 100\% & SPV EPC \\
& Modal & Hutang & \\
\hline NPV & USD 12,7 M & USD 22,5 M & USD 14 M \\
Payback & 5 tahun & 3 tahun & N/A \\
IRR & $22 \%$ & $82 \%$ & N/A \\
\hline
\end{tabular}

Hasil evaluasi analisa ekonomi ini dipertajam dan dikaji kembali dengan melakukan evaluasi sensitifitas. Adapun parameter yang digunakan untuk uji sensitifitas mencakup parameter produksi, pasokan pembangkit listrik, biaya modal, dan biaya truk pengangkut. Hasil evaluasi sensifitas dari pemodelan ekonomi dari proyek ini secara signifikan dapat dipengaruhi dengan simpulan sebagai berikut:

1. Peningkatan produksi nominal 7JTPT akan meningkatkan NPV proyek dari USD 22.5 menjadi USD $35.7 \mathrm{M}$

2. Untuk sumber pembangkit listrik dengan pasokan listrik diesel yang dihasilkan yaitu generasi diesel mengurangi NPV dari USD 22.5 M ke USD $18.5 \mathrm{M}$

3. Peningkatan biaya modal proyek sebesar $20 \%$ mengurangi NPV dari USD $22.5 \mathrm{M}$ ke USD $17.19 \mathrm{M}$

4. Biaya angkut truk dengan kenaikan nominal 15\% akan meningkatkan NPV proyek dari USD 22.5 ke USD $30.81 \mathrm{M}$

Selanjutnya hasil kajian kelayakan proyek secara teknis dan ekonomis ditindak lanjuti dengan melakukan analisa resiko tingkat tinggi dari rencana pelaksanaan proyek ini. Beberapa resiko tingkat tinggi yang menjadi perhatian yang perlu mendapatkan tindak lanjut kontrol agar pelaksanaan dan penyelesaian proyek tepat waktu dan sesuai dengan biaya dan fungsi. Berikut resiko tingkat tinggi yang tercakup dalam analisa resiko:

1. Keterlambatan persetujuan Direksi dan proses tender. Untuk memastikan risiko ini diminimalkan dengan memberikan kontrol persiapan dokumentasi teknis, penyusunan analisa ekonomi, pengajuan kapital, dokumentasi kontrak, rencana pelaksanaan proyek dan permintaan proses tender dilakukan secara paralel untuk mendapatkan persetujuan Direksi. Disamping itu proses tender, evaluasi teknis dan komersial proyek bisa ini cukup memakan waktu lama sekitar 16-20 pekan. Sehingga dengan sesaat persetujuan direksi diperoleh maka proses tersebut dapat segera dilaksanakan dengan menghilangkan resiko keterlambatan selama periode tersebut.

2. Resiko geoteknikal dilaksanakan untuk mengkaji resiko yang mengakibatkan peningkatan biaya pekerjaan sipil termasuk pekerjaan tanah dan pondasi. Untuk itu kontrol resiko yang diterapkan guna menekan dan mengkontrol resiko ini adalah dengan melakukan investigasi geoteknik awal. Investigasi ini bertujuan untuk menentukan lokasi stasiun peremukan, rute $O L C$ dan lokasi stasiun penghubung dengan stasiun yang ada yang paling optimal berdasarkan panjang minimal dan gangguan minimal terhadap operasi penambangan. Selanjutnya untuk menambah kontrol agar resiko ini lebih kecil lagi maka dalam ruang lingkup kerja kontraktor EPC ditambahkan perlunya tinjauan hasil investigasi geoteknik awal ini sebagai dasar diperlukannya keharusan melakukan investigasi geoteknik tambahan.

3. Resiko EPC adalah resiko tinggi dengan tekanan keterlambatan jadwal dan biaya proyek akibat dari dari ketersediaan dan kualitas kontraktor serta pengadaan peralatan utama yang memang membutuhkan waktu panjang untuk proses produksinya. Dari pengalaman KPC menetapkan kontrol yang tepat untuk keduanya adalah penerapan manajemen EPC yang tekun oleh pemilik dan kontraktor untuk memastikan kepatuhan terhadap rencana 
pelaksanaan proyek selama tahap rekayasa dan pengadaan proyek, dan melaksanakan penilaian risiko terperinci untuk setiap paket pekerjaan selama pelaksanaan EPC.

4. Risiko bisnis dan operasional adalah resiko ketergantungan pada truk pengangkut untuk memindahkan batubara, sehingga mengurangi resiko produksi dari kekurangan ban alat berat. Resiko ini bisa ditekan dengan kontrol penyelesaian instalasi overland conveyor tapi pada sisi lain dengan overland conveyor resiko operasional untuk gangguan dan berhenti produksi melalui satu dari kejadian bencana terjadi ke konveyor sangat tinggi dibandingkan dengan banyaknya truk pengangkut. Namun, dalam rencana biaya modal sudah mencakup pengadaan suku cadang utama sebagai jaminan untuk menutupi gangguan kasus terburuk yang mengharuskan dilakukan perbaikan besar. Dari pengalaman, KPC telah mengoperasi $O L C$ serupa selama beberapa 15 tahun dengan catatan yang sangat rendah gangguan produksi karena peristiwa bencana yang berdampak pada resiko bisnis.

Pada akhirnya Direksi KPC memutuskan untuk melaksanakan realisasi proyek dengan skema pilihan ketiga. Ketika proyek ini direalisasikan pelaksanaan proyek ternyata mengalami kendala dengan dibatalkannya proses tender pertama pada tahun 2007-2008 akibat dari resesi ekonomi dunia. Setelah masa resesi ekonomi dunia berlalu, pada awal tahun 2010 proses tender proyek ini dilanjutkan kembali. Akhirnya KPC menyetujui kontrak proyek dengan kontraktor EPC untuk memulai pelaksanaan proyek pada tanggal 1 Oktober 2010 dengan jangka waktu penyelesaian 21 bulan atau tanggal penyelesaiannya pada 30 June 2012. Akan tetapi secara aktual penyelesaian proyek ini mundur sampai pada akhir Desember 2014 akibat hambatan teknis dan operasional proyek yang terjadi di lapangan serta persoalan kontraktual.

Pada tahun 2015 sebagai tahun pertama operasi, Melawan Crushing Station dan Western Overland Conveyor hanya dioperasikan untuk persiapan operasi penuh. Sehingga pada tahun ini kapasitas produksi hanya dipasok hampir setengah dari kemampuannya dan pencatatan produksi belum begitu optimal. Selanjutnya pada tahun kedua dan tahun-tahun berikutnya, fasilitas ini telah mampu beroperasi penuh dengan menyerap hampir setengah dari produksi tambang Sangatta area. Dari catatan kinerja produksi KPC (CPHD, 2019) yang mencakup tonase produksi, kapasitas tonase per jam atau ton per hour (TPH), ketersediaan fisik atau physical availability (PA), dan pengoperasion atau usage dapat ditampilkan kinerja dan actual produksi fasilitas ini seperti pada tabel sebagai berikut:

Tabel 3. Kinerja dan Produksi Aktual

\begin{tabular}{lcccc}
\hline & 2015 & 2016 & 2017 & 2018 \\
\hline PA & $97 \%$ & $94 \%$ & $94 \%$ & $97 \%$ \\
Usage & $86 \%$ & $86 \%$ & $81 \%$ & $77 \%$ \\
THP rata-rata & 3,101 & 3,341 & 3,410 & 3,361 \\
Tonase (juta ton) & 13,878 & 24,775 & 24,029 & 22,567 \\
\hline
\end{tabular}

Dari catatan kinerja dan produksi aktual selama operasi 4 tahun awal dan dengan 3 tahun akhir operasi normal dapat dilihat bahwa operasi Melawan Crushing Station dan Western OLC ini sudah sesuai dengan desain yang diinginkan. Ini terbukti catatan physical availability fasilitas ini rata-rata per tahun mencapai $96 \%$ yang artinya dari total waktu yang tersedia terdapat $96 \%$ waktu operasi tanpa terganggu oleh kerusakan atau perbaikan secara terencana maupun tidak terencana. Nilai 96\% ini melebihi target yang ditetapkan perusahaan sebesar 93\%. Sementara usage dan TPH ratarata sedikit terpaut dari desain ini disebabkan oleh hambatan dari sisi eksternal operasional fasilitas dan inkonsistensi pasokan batubara dari tambang. Akan tetapi mengacu kepada rencana produksi yang dijadikan acuan analisa ekonomi, produksi aktual fasilitas ini sudah melebihi target yakni sebesar 18.9 Juta Ton pada 3 tahun terakhir atau 11.5 Juta Ton total 4 tahun pertama operasi.

Maka dengan beroperasinya fasilitas ini dengan kapasitas produksi 4000 TPH maka KPC telah menggantikan truk pengangkut batubara sebanyak 32 unit. Sementara jumlah tenaga kerja yang 
bisa dikurangi untuk operator truk pengangkut batubara yang berjumlah sampai 106 karyawan dengan mengoperasikan Melawan Crushing Station dan Western OLC hanya diperlukan 12 karyawan.

Berikut beberapa foto yang menggambarkan fasilitas Melawan Crushing Station dan Western OLC yang diambil dari udara (KPC, 2017):

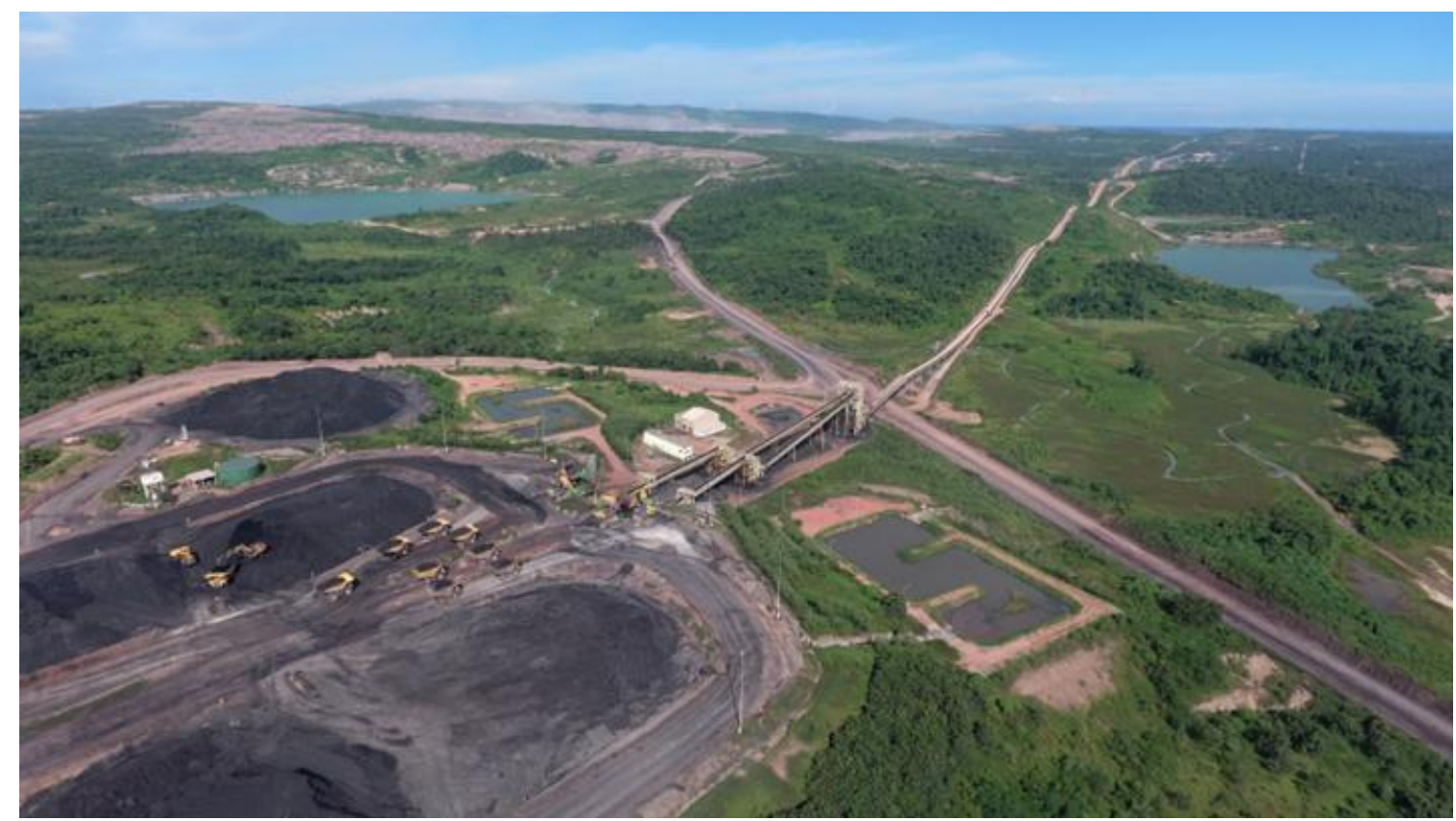

Gambar 5. Fasilitas Melawan Crushing Station dan Western OLC

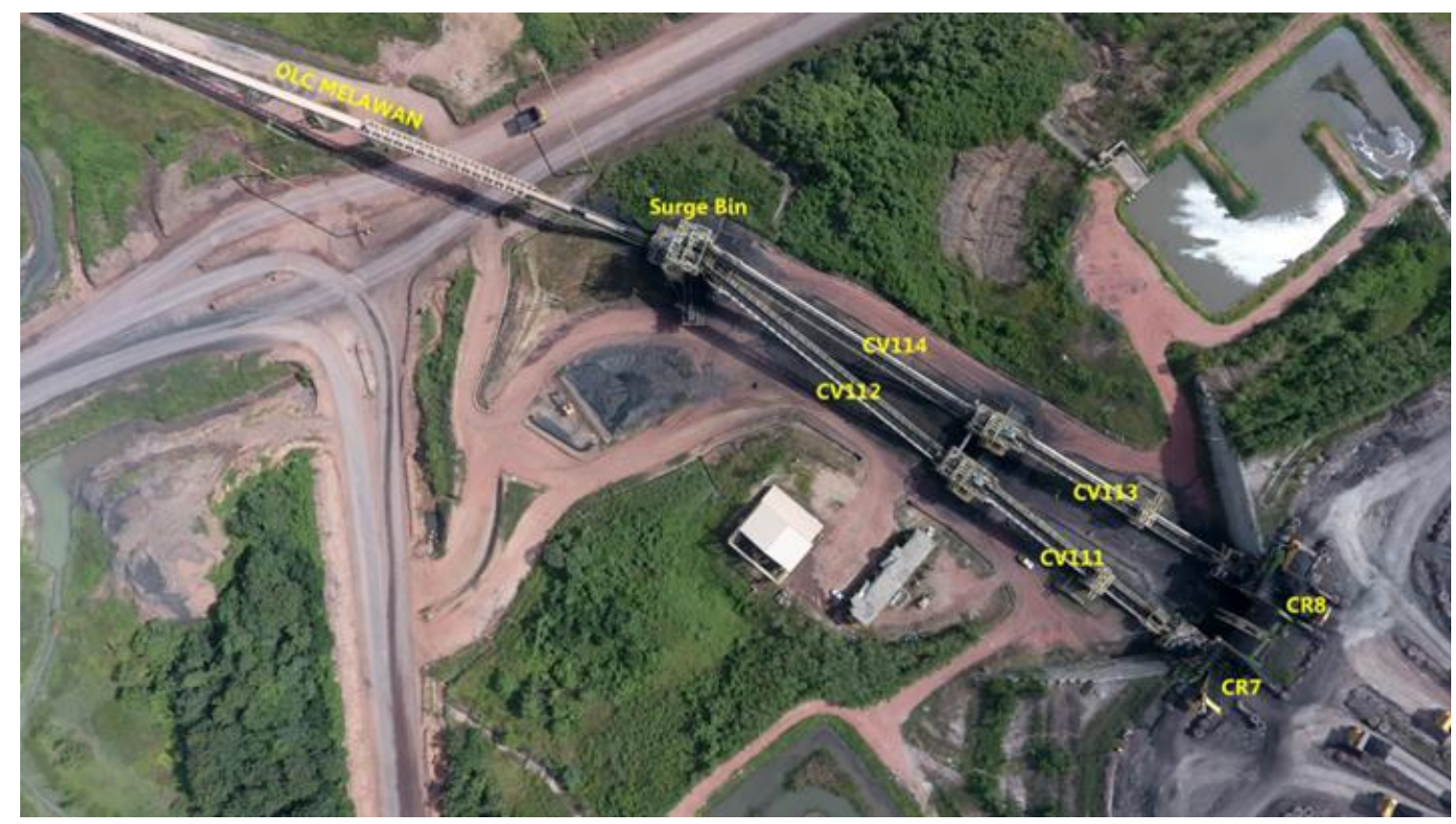

Gambar 6. Fasilitas Melawan Crushing Station dan Western OLC Bagian Tail End 


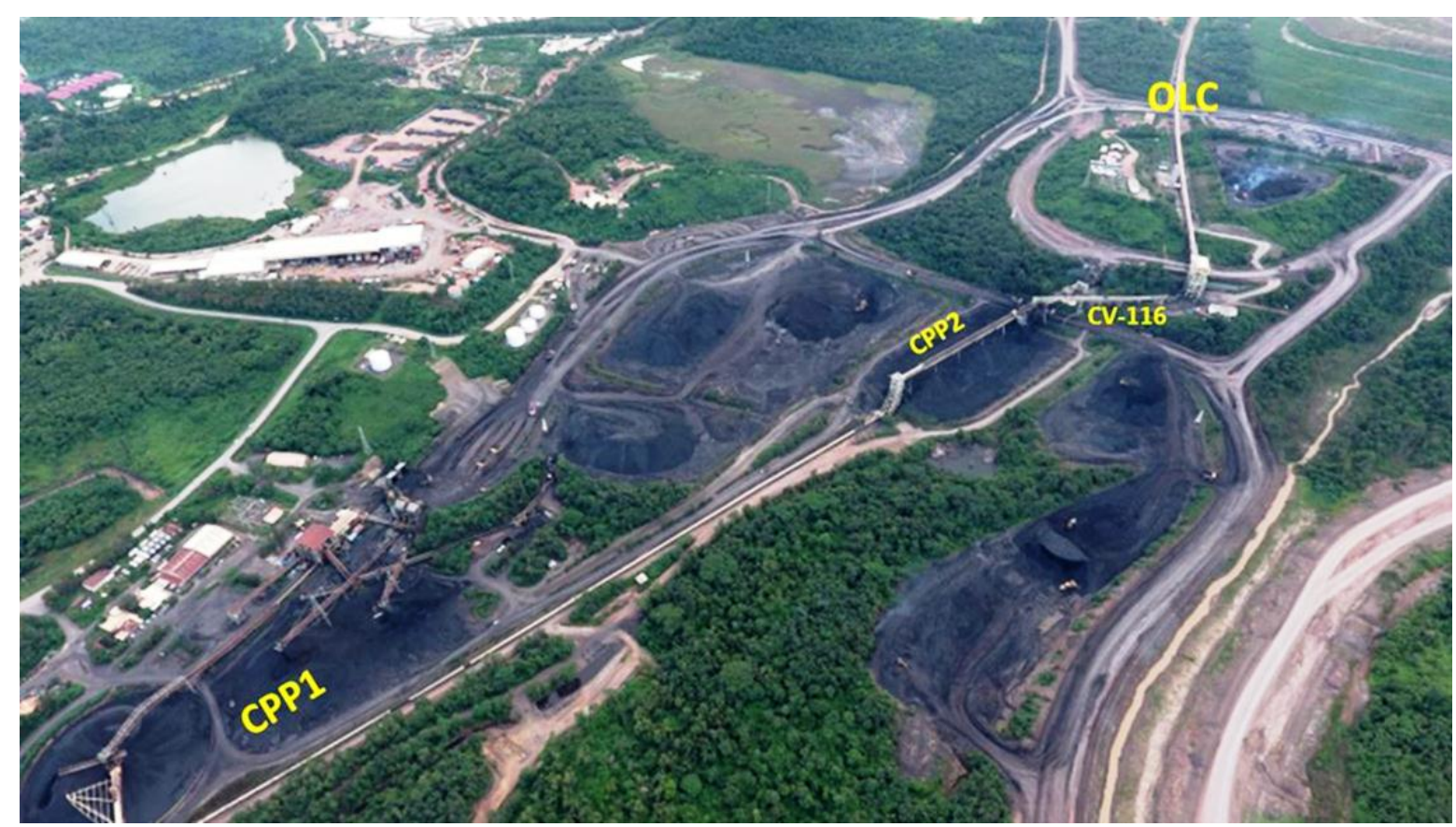

Gambar 7. Fasilitas Melawan Crushing Station dan Western OLC Terhubung dengan Fasilitas Coal Preparation Plant 2 (CPP2) Yang Sudah Ada

\section{SIMPULAN}

Dari paparan pembahasan di atas dapat diambil simpulan sebagai berikut:

1. OLC dapat menggantikan moda transportasi truk pengangkut batubara dengan memberikan ketersediaan waktu operasi dan kesempatan produksi yang lebih tinggi dibanding truk pengangkut.

2. OLC mampu menekan resiko kecelakaan dan penghentian operasi tambang. Keuntungan dicapai dengan menyediakan sumber daya manusia, peralatan dan interaksinya jauh lebih sedikit dibandingkan dengan moda transportasi truk pengangkut batubara.

3. OLC terbukti jauh mengurangi emisi karbon monoksidan dan pembuangan limbah hidrokarbon dibandingkan moda transportasi pengangkut batubara masih menggunakan truk.

4. Potensi produksi kedepan masih bisa ditingkatkan sampai dengan 30 Juta Ton per Tahun dengan meningkatkan TPH rata-rata sampai dengan 4000 dan usage sampai dengan $86 \%$.

\section{DAFTAR PUSTAKA}

Conveyor Equipment Manufacturers Association (CEMA) (2007): Belt Conveyors for Bulk Materials Sixth Edition 2nd Printing, Florida, United State of America, 13.

PT Kaltim Prima Coal (2010): Analisa Dampak Lingkungan, Peningkatan Kapasitas Produksi Batubara Hingga 70 Juta Ton per Tahun, II-29.

PT Kaltim Prima Coal (2019): Coal Handling \& Processing Division Equipment Performance 2015-2019

PT Kaltim Prima Coal (2010): Coal Chain Expansion Melawan Crushing Station \& Western Overland Conveyor Project Definition Statement Revision 1, 11-22.

PT Kaltim Prima Coal (2015): Coal Preparation Plant Isometric Expansion Plan Drawing 000G024 Revision A.

PT Kaltim Prima Coal (2017): Foto-Foto Fasilitas Melawan Crushing Station \& Western Overland Conveyor. 
PT Kaltim Prima Coal (2010): General Exisiting and Future Coal Chain Site Plan.

PT Kaltim Prima Coal (2019): General Flow Diagram - Sangatta Drawing 000G027 Revision D.

PT Kaltim Prima Coal (2006): Justification of Western Overland Conveyor to Melawan Region.

PT Kaltim Prima Coal (2007): Justification of Western Overland Conveyor to Melawan Region.

PT Kaltim Prima Coal (2007): Rencana Produksi Tambang Melawan Area LOM Versi 3.

Zisco Project - World Record data diperoleh melalui situs internet: http://conveyordynamics.com/index.php/project/zisco/ diunduh pada tanggal 9 September 2019. 
PROSIDING TPT XXVIII PERHAPI 2019 